\title{
A Fondness for Charts and Children: Scientific Progressivism in Vancouver Schools 1920-50
}

\author{
Gerald E. Thomson
}

\section{INTRODUCTION}

In January 1933, Vancouver newspaper reporter George Shem described school administrator and educator Robert Straight for the Sunday Province Magazine. Former elementary school principal and now expert educationalist, Straight had since 1927 headed a Vancouver school system department charged with gathering statistics and measuring the intelligence of the city's school children. Shem described him as "slightly pudgy" with "grey hair slicked back" and a tendency "to wave a small silver pencil about" when he spoke_- "a happy man" who sat behind his desk at the Bureau of Measurements "ponder[ing] his curves and straight lines.... He is that curious anomaly a man who is fond of charts and of children. He studies both." This comment neatly captures the central dilemma of the progressive scientific educator: what mattered more, their charts of statistics and test results, or the education of children?

School administrators Robert Straight, Herbert Baxter (H.B.) King, and Robert Sparling were leaders of a progressive education movement in Vancouver advocating scientific methods to reform the public education system. All three trained during the 1920 s at the University of Washington in the new progressive theory of public education based on scientific principles of management and efficiency. This "cult of efficiency" in education began in the United States around 1911, when American school administrators faced widespread criticisms of wastefulness and unbusinesslike management of public schools. ${ }^{2}$ Their response was to conceive of public schools as industrial sites. Students became raw material to be graded by intelligence testing, then educated after elementary schooling in academic or vocational tracks dictated by their natural abilities.

The scientific side of the progressive education movement came under attack in the 1960s, beginning with Callahan's historical work on American school administration. In the 1970s Marxist critics of education blamed scientific progressivism for the construction of an educational meritocracy that remains largely intact as we enter the new millennium. For my part, I will examine the introduction of scientific progressivism to the Vancouver school system through the administrative careers of Straight, King, and Sparling. Their common education at the University of Washington and their personal and professional friendship were

I"City Schools Go Straight," Sunday Province Magazine, 22 January 1933, 8.

${ }^{2}$ Raymond E. Callahan, Education and the Cult of Efficiency: $A$ Study of the Social Forces That Have Shaped the Administration of the Public Scbools (Chicago: University of Chicago Press, 1962), 52-64.

(C) Historical Studies in Education/Revue d'bistoire de l'éducation 12, nos. 1/ 2 (2000): 111-28. 
highly significant in the history of British Columbia's educational system. The older Sparling would die before acquiring a lasting presence in the province's public school system, but Straight would head the first "urban efficiency bureau" in the Canadian public school system, and King become head of Canada's first junior high school, and later Chief Inspector of Schools.
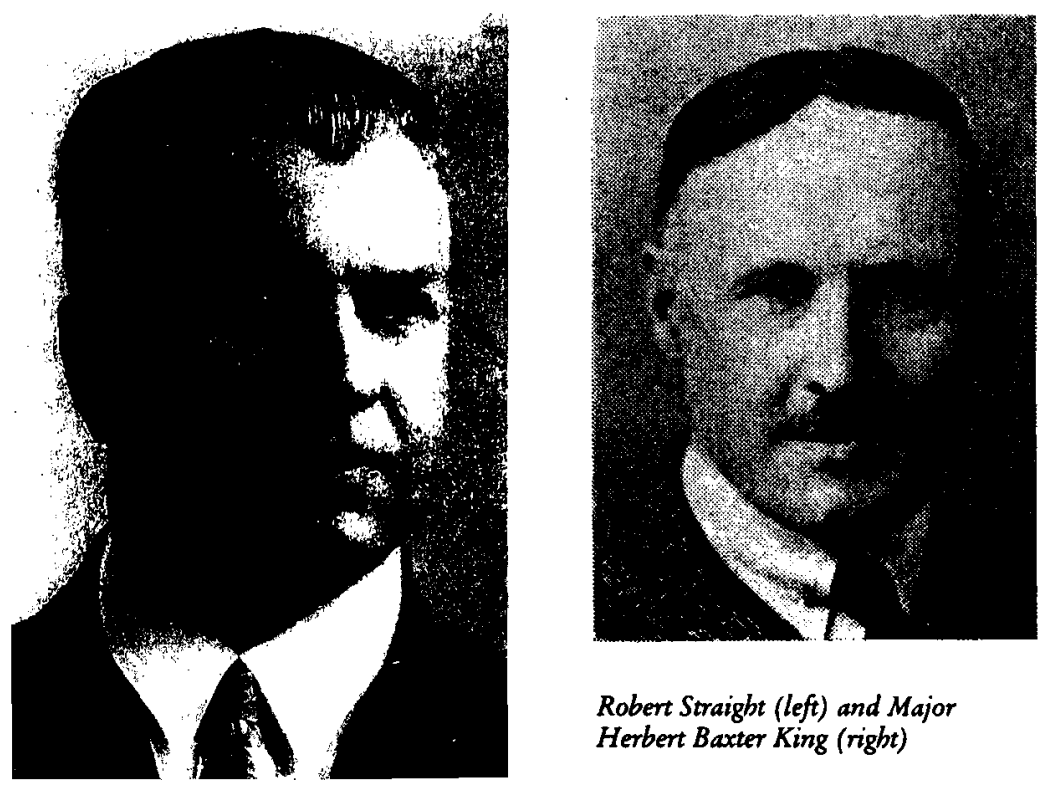

Robert Straight (left) and Major Herbert Baxter King (right)

These images are probably from the early 1930 s, as the likeness of Straight corresponds to striking photographs of him that preceded his annual reports in the Vancouver Board of School Trustees' Annual Reports of the same period. Source: K.A. Waites, Vancouver High Schools: The First Fiffy Years, 1980-1940 (Vancouver School Board, 1940), King: p. 65, Straight, p. 64.

\section{HISTORICAL REASSESSMENT OF NORTH AMERICAN}

PROGRESSIVE EDUCATION

Historians' reassessment of progressive education in North America began in the 1960 s in the United States, and by the late 1970s in British Columbia. Lawrence Cremin's 1961 The Transformation of the School placed the end of the American progressive educational movement at 1955, with the demise of the Progressive Education Association and its journal Progressive Education. He argued such progressive reforms as vocational education and differentiated curriculum (supposedly to suit each student's ability) had transformed a "restricted" education system into 
one "realizing the promise of American life," recasting the "school as a fundamental lever of social and political regeneration."

The first attack on scientific progressivism, as misguided practice, was Callahan's Education and the Cult of Efficiency. Adoption of business methods by American school administrators to manage overcrowded and underfunded public schools became "an American tragedy in education." The emphasis on lowered costs, the sorting of students into ability tracks and platooning of classes to churn out a high volume of products (graduates) mired American public education in management trivialities. Callahan saw the "essence of the tragedy" as indiscriminate application of efficiency measures "with little or no consideration of educational values or purposes." Callahan's rebuke of progressive school administrators was echoed in an early work by Sol Cohen. ${ }^{5}$

This reassessment of American progressivism gained strength in the late 1960 s with the appearance of educational historians Cohen calls "radical revisionists." During the 1970 s a still more critical group of theorists called the "New Left" employed Marxist and socialist historical perspectives. Whatever label one applies to these historians of American education, they all, according to Cohen, "ceased writing about the public school as if it were unequivocally progressive." In their collection Roots of Crisis (1973), Clarence J. Karier, Paul C. Violas, and Joel Spring challenged Cremin's notion of progressive school reforms as prosocial and democratic. They treated these reforms as an overt extension of social controls over free individuals by the American business elite. By World War I the American public school system was shaping students according to the labour needs of the corporate state. In the quest for "the efficiency goal," wrote Karier, the "progressives would use the compulsory power of the State." "Scientific" school initiatives were "without question, conservative." Others such as Colin Greer and Michael B. Katz advanced the notion that progressive school reform had more to do with social/industrial order than learning. ${ }^{8}$

When Samuel Bowles and Herbert Gintis published Schooling in Capitalist America (1976), replete with a Marxist theory of public education as a merito-

${ }^{3}$ Lawrence A. Cremin, The Transformation of the School: Progressivism in American Education 1876-1957 (New York: Vintage, 1961), 88.

${ }^{4}$ Callahan, Cult, op. cit., 244.

${ }^{5}$ Progressives and Urban School Reform (New York: Teachers College Press, 1964). See also Cohen's recent essay "The Influence of Progressive Education on School Reform in the U.S.A." in Hermann Rohrs and Volker Lenhart, eds., Progressive Education Across the Continents: $A$ Handbook (Frankfurt am Main: Peter Lang, 1995), 321-31.

'Sol Cohen, "History of Education as a Field of Study: An Essay on Recent Historiography of American Education," in Donald R. Warren, ed., History, Education, and Public Policy (Berkeley: McCutchan, 1978), 40.

'Clarence J. Karier, "Liberal Ideology and the Quest for Orderly Change," in Clarence J. Karier, Paul C. Violas and Joel Spring, Roots of Crisis: American Education in the Twentieth Century (Chicago: Rand McNally, 1973), 88-91.

${ }^{8}$ See Colin Greer, The Great School Legend: A Revisionist Interpretation of American Public Education (New York: Viking, 1972) and Michael B. Katz, Class, Bureaucracy and Schools: The Illusion of Educational Change in America (New York: Praeger, 1975). 
cracy, subservient to a capitalist hierarchy of labour, the democratic ideals of progressive educational reforms were in tatters. For Bowles and Gintis the

particular concerns of the Progressives-efficiency, cooperation, internalization

of bureaucratic norms and preparation for variegated adult roles-reflect the

...organization of production in the giant corporate enterprises.'

Even less doctrinaire historians of American education reached similar conclusions. By adopting a "corporate model of governance" the administrative progressives became "focused upon differentiating" school children in order to fulfil "the goals of social efficiency and social control" through what David B. Tyack called their One Best System. ${ }^{10}$ Diane Ravitch called progressive educational reform a "troubled crusade" that hindered authentic school reform." Even Cremin acknowledged intelligence tests had produced "a host of inequalities," though he nonetheless believed Americans saw public schools as a mechanism of social uplift on which they "increasingly pinned their millennialist hopes and aspirations." 12 Paula S. Fass meanwhile characterized public education as a coercive system designed to frustrate minority students. Her Outside In: Minorities and the Transformation of American Education concluded progressive educational theorists sought to channel individuals into social slots "according to the range of their educability." ${ }^{13}$ Scientific progressive education in American public schools was a socially conservative movement that served economic ends rather than individuals' learning requirements.

The few historical works on progressive education in British Columbia date from the early 1980 s and were influenced by previous reassessments of progressive education in the United States. Jean Mann in 1980 wrote a helpful analysis of the careers of George M. Weir and H.B. King, and particularly of the 1925 Putman-Weir Survey of the British Columbia School System, as the mechanism traditionally regarded as introducing progressive education into B.C. public schools. George Weir, first Professor of Education at the University of British Columbia [UBC] in 1923, and J.H. Putman, a senior inspector in the Ottawa school system, wrote an American-style study of British Columbia's schools recommending reform along progressive lines. Mann also examined the later career of H.B. King and his Report on School Finance (1935). This is the very King, later Chief Inspector of Schools in 1937, whose early education and administrative career are the subject of this paper.

9Samuel Bowles and Herbert Gintis, Schooling in Capitalist America: Educational Reform and the Contradictions of Economic Life (New York: Basic Books, 1976), 235.

${ }^{10}$ The One Best System: A History of American Urban Education (Cambridge, Mass.: Harvard University Press, 1974), 196.

${ }^{11}$ See Diane Ravitch, The Troubled Crusade: American Education, 1945-1980 (New York: Basic Books, 1983), Chapter 2: "The Rise and Fall of Progressive Education," 43-80.

${ }^{12}$ Lawrence A. Cremin, American Education: The Metropolitan Experience, 1876-1980 (New York: Harper \& Row, 1988), 234.

${ }^{13}$ Paula S. Fass, Outside In: Minorities and the Transformation of American Education (New York: Oxford University Press, 1989), 51. 
Mann emphasized progressivism as "a many-faceted movement," and the type of progressivism advocated by the Putman-Weir Survey as a "melange of many... educational theories of the time which fell under the rubric of progressive education." For all their rhetoric of stifling formalism and their view that "tradition" held back the schools, Putman-Weir advanced reforms from the conservative side of American educational progressivism. They advised a differentiated form of education for students beyond the elementary level to foster "vocational guidance and proper work attitudes." Mann forcefully argued that after 1925, British Columbia schools adopted a policy of "promotion of scientific efficiency, practicability and vocationalism, and testing and measurement in education. ${ }^{14}$ She identified this progressivism as the product of a middle-class, professional campaign to manage scientifically the public schools.

A.H. Child published even before Mann a portrait of King as anything but a "radical progressive," citing his promotion of "standardized tests and inventories" and his "vague statements" about their use as evidence of King's social conservatism. ${ }^{15}$ Unlike Mann, Child failed to recognize a larger pattern of socially conservative policies promoted through progressive educational reform. Meanwhile, Timothy A. Dunn wrote on vocational streaming, showing that progressive reformers gave technical education a scientific rationale: differentiated education based upon students' natural ability as measured by intelligence tests.

Vancouver's Technical High School and New Westminster's T.J.Trapp Technical High School were established to complement manual training in the junior schools by the mid-1920s. Dunn believed progressive notions of "character formation" dominated these school vocational programmes. The goal was "an efficient education system... open to the masses" in which all "children could maximize their potential as citizens. ${ }^{16}$ Dunn later argued the province's educational leaders began to use schools to promote social stratification to make students "socially efficient citizens" and to reduce high school dropout rates.

Mann called educational testing "one of the foundation stones of progressive education." Social class background, ethnicity, and mental subnormality could influence test results and thus serve as a "guidance as to a person's moral worth." Testing would decide each child's educational course in the province's school

${ }^{14} \mathrm{Jean}$ Mann, "G.M. Weir and H.B. King: Progressive Education or Education for the Progressive State?" in J. Donald Wilson and David C. Jones, eds., Schooling and Society in Twentieth Century British Columbia (Calgary: Detselig, 1980), 91, 93-4.

${ }^{15}$ A.H. Child, "Herbert B. King: Administrative Idealist," in Robert S. Patterson, John W. Chalmers, and John W. Friesen, eds., Profiles of Canadian Educators (Toronto: D.C. Heath, 1974), 316.

${ }^{16}$ Timothy A. Dunn, "Teaching the Meaning of Work: Vocational Education in British Columbia" in David C. Jones, Nancy Sheehan, and Robert M. Stamp, eds., Shaping the Schools of the Canadian West (Calgary: Detselig, 1979), 246, 252-3. 
system. $^{17}$ Later work by McLaren on mental hygiene ${ }^{18}$, by Thomson on eugenics ${ }^{19}$, and by Gleason on intelligence testing ${ }^{20}$ suggested how, in a "psychologized" classroom, children are understood according to the labels applied to them.

Finally, Neil Sutherland's interview work for the Canadian Childhood History Project in the early 1980 s showed how formalism dominated the elementary schools and shaped "what actually went on in classrooms." Despite initiatives to transform curriculum and change teaching methods, a set pattern of formalism dominated the conduct of education. Sutherland concluded that in the mid-1960s "some began to take seriously the child-centred rhetoric of... educational literature and to insist that it be employed in the schools. ${ }^{\text {21 }}$ Formalism may be seen as another manifestation of the conservative scientific progressivism advanced by educational reformers in the 1920 s. As Sutherland defined it, formalism falls neatly in line with the school routines and devices of educational efficiency. Sutherland recommended local historical case studies of school systems and their leaders to better understand the course of "progressive" education. My research is a response to this invitation.

\section{SCIENTIFIC PROGRESSIVISM IN VANCOUVER'S SCHOOLS, 1920-50}

School Inspector J.T. Pollock's 1920-21 report noted many Vancouver teachers "attending summer school and taking special courses during summer vacations in Washington and in California." Their "desire to increase their own efficiency" as teachers by reading the works of Ellwood Cubberley, George Strayer, Guy Montrose Whipple, Alfred Binet, Lewis Terman, Arthur Otis, and Leonard Ayres was admirable, but some outsiders, Pollock warned, would find their zealousness for new ideas "disquieting." He warned these "earnest and conscientious teachers [,] who believe in rapid and radical" methods of education, that they should be wary, as the "royal road to learning has not yet been discovered."22 For Straight, King, and Sparling, this had been revealed to them early in their careers

\footnotetext{
${ }^{17}$ Mann, "Weir and King," op. cit., 98-9.

${ }^{18}$ Angus McLaren, Out Own Master Race: Eugenics in Canada, 1885-1945 (Toronto: McClelland \& Stewart, 1990), 92-103.

${ }^{19}$ Gerald E. Thomson, "Remove From Our Midst These Unfortunates," PhD thesis, University of British Columbia, 1999.

${ }^{20}$ Mona Gleason, Normalizing the Ideal: Psychology, Schooling, and the Family in Post-War Canada (Toronto: University of Toronto Press, 1999), 128-32.

${ }^{21}$ Neil Sutherland, "The Triumph of 'Formalism': Elementary Schooling in Vancouver from the 1920s to the 1960s" in Jean Barman, Neil Sutherland, and J. Donald Wilson, eds., Children, Teachers and Schools in the History of British Columbia (Calgary: Detselig, 1995), 101, 121; originally published in B.C. Studies 69-70 (Spring-Summer 1986): 175-210. For Sutherland's analysis of progressive education in Canada or the "new education," see his Children in EnglishCanadian Society: Framing the Twentieth Century Consensus (Toronto: University of Toronto Press, 1976).
}

${ }^{22}$ J.T. Pollock, "Report of Inspectorate No. 3," Fiftieth Annual Report of the Public Schools of British Columbia (1920-1921), F 23. 
as elementary principals, when they had been convinced American scientific progressivism was the royal road to educational reform in Vancouver's schools.

These three men came to Vancouver schools at different stages of life. Robert Straight was born 25 December 1885 in East Florenceville, New Brunswick, and graduated from the Provincial Normal School in 1904. He came to British Columbia with his new wife in 1907 and taught at Kitsilano and Central Elementary Schools. By 1911 he was principal at Grandview Elementary and in 1914 moved to Lord Tennyson Elementary, where he would remain until he was appointed Director of the new Bureau of Measurements in $1927 .{ }^{23}$ Straight remained head of the Bureau until he retired due to ill health in 1951, dying in 1956.

Herbert Baxter King was born in Perth County, Ontario, on 15 January 1879. After graduating from the University of Toronto in 1899 he taught for one year in the schools of his native Walkerton/Bruce County. He left in 1903 for Vancouver and began teaching at General Gordon Elementary School in 1904. He served in World War I, reaching the rank of Major, a title he kept all his life. Eventually he was appointed principal at General Gordon and in 1927 became head of Canada's first Junior High School, Kitsilano. King attended university constantly, earning a B.A. from Queens in 1913, an M.A. in Philosophy from $\mathrm{UBC}$ in 1924, and a Ph.D. in 1936 from the University of Washington in Seattle. After his 1935 report on school financial reform, King was appointed Chief Inspector of Schools in 1937, retiring in 1946. ${ }^{24}$

Robert Sparling was born 8 August 1862 near Seaforth, Ontario. He came to British Columbia in 1893 and taught school for five years in Vernon. In 1898 he relocated in Vancouver and taught at several schools before becoming principal of Aberdeen Elementary in 1908. Sparling was active in the Provincial Teachers Federation, and helped found the Child Welfare Association of British Columbia in 1918. Although he was older than Straight or King, all three became close friends and colleagues. ${ }^{25}$

K.A. Waites' local history of Vancouver's schools mentions that three principals began after 1912 to promote new scientific techniques in education. Straight of Lord Tennyson Elementary, King of General Gordon Elementary, and Sparling of Aberdeen Elementary became "among the most active proponents of an up-to-date curriculum and application of new scientific methods in education."26 In 1919 the three began to attend the summer quarters of the School of Education at the University of Washington campus. The rationale for travelling to Seattle was strong, as UBC had no Education Department until 1924 and offered few education courses-and those only through the Philosophy

\footnotetext{
${ }^{23}$ Interview with Lee Straight, 5 March 1997; "Obituary Column: Veteran Educator, R. Straight, Dies," Province, Wednesday, 1 February 1956, 42.

${ }^{24}$ A.H. Child, "Herbert B. King: Administrative Idealist" in Patterson et. al., eds., Profiles, op. cit., 308; Interview with Lee Straight, 5 March 1997.

25"Mr. Robert Sparling," The B.C. Teacher 4, 8 (April 1925): 179.

${ }^{26} \mathrm{~K}$.A. Waites, The First Fifty Years: Vancouver High Scbools 1890-1940 (Vancouver: Vancouver Board of School Trustees, 1941), 62.
} 
Department. In 1919 Sparling and King began with a course in "Educational Measurements" taught by a Professor Hines from Los Angeles. Straight took the same course with Hines in 1921. The course "was designed to familiarize the student with the standard scales and tests" used in American public schools, and was "primarily intended for superintendents, principals and supervisors."27 The three Vancouver principals extended their professional education by immersing themselves in the latest tools of scientific progressivism, educational tests. Their work lay in that direction.

In 1921 Straight and Sparling took "Child Accounting and School Adjustment," a course on intelligence testing as a guide to "differential teaching. ${ }^{, 28} \mathrm{King}$ temporarily abandoned his course work until 1924 to pursue an M.A. at UBC on "Modern Theories of Instinct." Straight and Sparling took a variety of courses in the early 1920 s towards their own Masters degrees in Education. In 1922 Straight and Sparling enrolled in "The School Principal" and "The Elementary School Curriculum." Straight's son Lee recalled: "It was ordained or made a rule that administrators or principals had to have a B.A., or preferably, an M.A." He remembered this period of his childhood most vividly because his father relocated the entire family to Seattle one year during the early 1920 s while studying. ${ }^{29}$ In 1924 Sparling took his last summer quarter at the University of Washington in "Educational Sociology" and "Silent Reading." Sparling's "intention" was to write his Master's thesis in the next summer quarter. ${ }^{30}$ Instead, after a teaching career of thirty years, he became ill and died in March 1925.

After 1924 King returned to the University of Washington but took only "Abnormal Psychology," which offered explanations "of unusual behavior and the influence of the subconscious mind upon conduct. ${ }^{311}$ Straight's academic work included several aspects of scientific progressivism, as for instance his 1923 course on "School Surveys" with Professor Pittenger of Texas. The school survey was a vital mechanism of progressive school reform, according to Callahan, and would be realized in British Columbia through the 1925 Putman-Weir Survey of the School System. In 1924 Straight took a course on the "Psychology of Exceptional Children." King and Straight came under the influence of Dr. Stevenson Smith, whose views on the mental ability of school children were based upon eugenic hereditarianism. Smith, in General Psycbology in Terms of Bebavior

${ }^{27}$ Transcripts of the University of Washingron: Robert Sparling, Robert Straight and Herbert Baxter King; Bulletin: University of Washington, Summer Quarter, 1920, "Educational Measurements" 186-7, 29.

${ }^{28} \mathrm{Ibid}$.; Bulletin: University of Washington, Summer Quarter, 1921, “Child Accounting and School Adjustment" 201, 31; “General Psychology” 15a, 57.

${ }^{29}$ Ibid.; Bulletin: University of Washington, Summer Quarter, 1922, "The Elementary School Curriculum" 175 and "The School Principal" 190, 34; Interview with Lee Straight, 5 March 1997.

${ }^{30}$ Ibid.; Bulletin: University of Washington, Summer Quarter, 1924, "Educational Sociology" 151, 28 and "Silent Reading" 198b, 30; "Mr. Robert Sparling" (1925), op. cit., 179.

${ }^{31}$ Ibid.; Bulletin: University of Washington, Summer Quarter, 1925, "Abnormal Psycho$\log y^{\prime \prime} 126 a, 45$. 
(1921), asserts "some men are gifted with brains, and some are handicapped by a natural inferiority for which no amount of training will compensate." Generally "bright parents have bright children, mediocre parents have mediocre children, and dull parents have dull children." Any "exceptions to this rule should not be given any undue weight. ${ }^{32}$ Education could not overcome inborn mental deficits and differentiating a child's education on the basis of his or her mental ability was not only reasonable but created desirable efficiencies.

In 1926 King took up graduate work at the University of Washington with courses on "Mental Hygiene," "Educational Measurements," "Educational Statistics," and "Applied Psychology." ${ }^{33}$ He would write a 1936 thesis on school finance reform in British Columbia promoting centralized administrative control and efficiency strategies consistent with scientific progressivism. Robert Straight thought of changing his goal from an M.A. to a doctoral degree, according to his son, but the Great Depression frustrated his plans. By 1927 Straight was fully occupied with launching the new efficiency and testing agency in the Vancouver school system, created in the wake of the Putman-Weir Survey: the Bureau of Measurements.

The influence of the University of Washington on Vancouver public schools in the 1920s, and indeed the entire province, has never been explored. In September 1926, The B.C. Teacher reported "fully twenty B.C. teachers" attended "courses in Educational Measurements, Educational Psychology and [the] Philosophy of Education" at the University of Washington ${ }^{34}$ As early as 1923 The B.C. Teacher promoted education courses at the University of Washington and told its members it would be a "good time for teachers to meet [American] superintendents and board members. ${ }^{35}$ The British Columbia Teachers' Federation invited the President of the University of Washington to speak at their 1923 convention on American school reforms and school surveys. ${ }^{36}$ The University of Washington thus served as a conduit for the importation of American scientific progressivism.

The courses Straight, King, and Sparling took from instructors such as Dr. Stevenson Smith equipped them to see school children anew, or affirmed already-held attitudes. Sparling spoke as early as 1918 of education being provided

\footnotetext{
${ }^{32}$ Ibid.; Bulletin: University of Washington, Summer Quarter, 1925, "Recent Research in Human Behavior" 140a and 140b, 45; Stevenson Smith and Edwin Guthrie, General Psychology in Terms of Bebavior (New York: D. Appleton, 1921), 70-74.

${ }^{33}$ Ibid.; Bulletin: University of Washington, Summer Quarter, 1926, “Educational Statistics" 206, 33; “Seminar in Educational Measurements" 285, 33; “Applied Psychology" 121 b; "Mental Hygiene" 162b, 48.

34"The University of Washington," The B.C. Teacher 6, 1 (September 1926): 31-2.

${ }^{35}$ "University of Washington, Summer Quarter, 1923," The B.C. Teacher 2,7 (April 1923): 176.

${ }^{36}$ Dr. Henry Suzzallo, "A Modern Democratic School System," The B.C. Teacher 2, 7 (April 1923): 175-6.
} 
for children at different levels " for which nature has best fitted them. ${ }^{\text {"37 }} \mathrm{King}$ would organize the first junior high school in Canada on educational tracks, with students selected by intelligence tests-and Straight would head the agency conducting those mental tests. To these $V$ ancouver principals the royal road to school reform had to be both scientific and efficient in order to be progressive.

\section{SCIENTIFIC PROGRESSIVISM AT WORK: STRAIGHT'S BUREAU OF MEASUREMENTS AND KING'S DIFFERENTIATED JUNIOR HIGH SCHOOL}

\section{Straight and the Vancouver School System's Bureau of Measurements}

In the 1924/1925 school year Robert Straight oversaw the first structural reform in the Vancouver public school system. As principal of Lord Tennyson Elementary School, he implemented a "platoon" system of class scheduling: "The first school of the kind in Western Canada. ${ }^{38}$ Straight was applying a cost-saving measure popular in crowded American urban school districts directly to British Columbia. The "platoon" scheduling plan had been developed in 1906 by William A. Wirt, superintendent of the Bluffton, Indiana school system. Elementary school children rotated from class to class, while one teacher taught the same subject lesson over and over again. Expanded in 1908 by Wirt to cover the entire public school system of Gary, Indiana, it became known as the "Gary Plan." The result was an "improved school machine," according to Wirt, who reported with delight that one of his principals used the existing teachers in an eight-room school to teach double the number of pupils. Progressive educator and educational efficiency expert John Bobbitt of the University of Chicago called platooning a new tool for the "elimination of waste in education." ${ }^{\text {" }} 9$

Straight's results at Tennyson spoke for themselves: 643 pupils were taught by 16 teachers for a pupil/teacher ratio of 40 to 1 before platooning. After platooning 776 pupils were taught by 20 teachers for a pupil/teacher ratio of 39 to 1 . There were 133 more pupils but only 4 more teachers, and a school which taught more children without need for a costly building addition. ${ }^{40}$ Straight used only $\$ 3,380$ for remodelling to create "a sixteen room building with a small gymnasium" that would be overcrowded if not platooned. Inspector J.S. Gordon credited Straight as "a principal with a genius for organization and a clear understanding of platoon-school methods." Such a school would "render splendid service," Gordon asserted, and by the next year three more schools would be

\footnotetext{
${ }^{37}$ Report of the First Annual Convention of the Child Welfare Association of British Columbia, Vancouver, December 12, $13 \& 14,1918,8$.

${ }^{38}$ J.S. Gordon, "Vancouver City Schools," Fifty-Fourth Annual Report of the Public Schools of British Columbia (1924-1925)," Vancouver's First Platoon School:, M43-M44.

${ }^{39}$ Callahan, Cult, op. cit., 131.

${ }^{40}$ Fifty-Third Annual Report of the Public Schools of British Columbia (1923-1924), "Statistical Returns," T46; Fifty-Fourth Annual Report of the Public Schools of British Columbia (1924-1925), "Statistical Returns," M48.
} 
reorganized along platoon lines. ${ }^{41}$ Straight raised his status in the Vancouver school system through his efficiency-minded scheme. At a time when taxpayers were loath to approve school expansion budgets through higher property taxes, Straight offered a practical scheme for saving funds yet educating more students. Platooning had spread province-wide by 1927 , when Kelowna principal Colin Lees wrote that his school was able to "use our plant to $100 \%$ capacity." 42 Platooning was the first structural innovation of scientific progressivism brought into the schools of Vancouver by Straight, but it would by no means be the last.

The Putman-Weir Survey of the Schools (1925) specifically recommended creation of a Vancouver Bureau of Measurements to establish promotion "norms and standards [which] could be scientifically determined and applied to all schools in the city." The head of this agency must be an "expert educationist" assisted by "an able psychologist and one secretary. ${ }^{\text {"3 }}$ In many American cities such school bureaus served as test screening agencies to group pupils more efficiently for instructional purposes. In 1927 Straight was selected to head such a bureau for Vancouver's schools and promptly dispatched "to visit other cities and make a careful study" of how they conducted this "new sphere of work." ${ }^{34}$ Straight's son recalled his father touring the Ford factory while in Detroit. ${ }^{45}$ Back in Vancouver in the fall of 1927, Straight got right down to work. By June of 1928 he had instituted screening tests including the Terman Intelligence Test, National Intelligence Test, Woody-McCall Mixed Fundamentals in Arithmetic, and MonroeReasoning Test in Arithmetic, gathering data so "Principals were enabled to group their pupils according to ability. ${ }^{n 46}$ Results from the Terman Group Test-Form A indicated students receiving recommendations to high school were well within average to above-average I.Q. ratings. Pupils over 16 years of age not recommended for high school had a median I.Q. of 86.4, the "dull" range, and were assigned to pre-vocational classes at Fairview or the Technical High School. In its first school year, the Bureau of Measurements under Straight had fulfilled its mandate, sorting Vancouver's adolescent students into educational tracks. Principals dealing with students of low ability were now "in a better position to give advice concerning such pupils' future education." ${ }^{.47}$ Scientific progressivism had become the organizational logic of the entire Vancouver school system.

Expansion of high school education beyond grade 9 into technical/vocational programmes in the late 1920 s was a direct result of educational testing. The PutmanWeir Survey had recommended extension of vocational education to stem the high

${ }^{41}$ Gordon, op. cit., M43-M44.

${ }^{42}$ Colin Lees, "The Small Platoon School," The B.C. Teacher 7, 2 (October 1927): 35.

${ }^{43}$ J.H. Putman and G.M. Weir, Survey of the School System (Victoria: King's Printer, 1925), 434, 426.

${ }^{41}$ J.S. Gordon, "Vancouver City Schools," Fifty-Sixth Annual Report of the Public Schools of British Columbia (1926-1927), "Bureau of Measurements," M45.

"Interview with Lee Straight, 5 March 1997.

${ }^{46}$ Straight, "Bureau of Measurements," Vancouver Board of School Trustees (B.S.T.) Annual Report for 1927, 57.

47 Ibid., 62, 64. 
leaving rate after grade 9 . Key to the process was student selection by testing, as Mann points out. To this end Straight's Bureau constantly monitored younger children through achievement tests including the Detroit First-Grade Intelligence Test, Thorndike-McCall Reading Test, and Haggerty Reading Test. Straight created a yearly "Age-Grade Table" to track the "retardation rate" in Vancouver schools, employing twenty columns of cross data for grades 1 to 12, thirty-two categories of age calculations from 5.5 to 21 years old, and grade totals for underage, normal age, overage, and accelerated pupils. Since the work of Leonard Ayres in 1909 on overage students or "laggards" who impeded the work of the public school system, educators had used such data to monitor school efficiency. Straight's first Age-Grade Table for 1927 showed the largest group of overage pupils in grade $7(1,161)$ and grade 8 $(1,164) .^{48}$ These data justified the opening of the first junior high school in Canada with ability streaming in the Kitsilano area of Vancouver, and future plans for a vocational high school in East Vancouver. Overage students could be promoted if a high school education appropriate for their mental ability were provided.

Scientific progressivism was embraced by Vancouver school officials. Inspector J.S. Gordon wrote that

reliable diagnoses of the mental capacity of pupils, obtained through scientifically

conducted tests, at these critical periods, ensures better classification for teaching purposes.

Counsellors could now scientifically "direct...students in the choice of secondary school courses." Gordon felt the high failure rate in high school could be eliminated as many "students start on high school courses for which they are not naturally fitted."49

Vancouver schools were evolving towards the progressive vision Straight had adopted at the University of Washington: a school system organized on principles of scientific measurement and social preparation for the modern industrial era.

A regular pattern of seasonal testing developed through the late 1920 s. In the fall grade 8s took the Terman Group Test and data were gathered for the AgeGrade Table. In the spring grade-wide screening tests of elementary children tracked achievements in reading, mathematics, and writing. Weak students were referred to the school psychologist, Miss Ruby Kerr, for individual testing with the Stanford-Binet. In 1928 she tested 481 pupils, many then added to the growing special classes for subnormal children supervised since 1910 by Miss Josephine Dauphinee. These special classes swelled after Straight's grade-wide screening tests and classifications, and by 1927 a junior high school programme for "subnormals" began. Straight saw his screening work as vital: "[The] greatest task confronting us to-day is the problem of adapting instruction to meet the needs and capacities of individual pupils. ${ }^{\text {"50 }}$ In 1929 Straight and Kerr conducted a city-wide reading

${ }^{48}$ Ibid., 73-6, Table 8; Callahan, Cult, op. cit., Leonard Ayres on Laggards, 15.

${ }^{49} \mathrm{~J} . S$. Gordon, "Report of the Municipal Inspector of Schools," Vancouver B.S.T. Annual Report for 1927, “Bureau of Measurements," 27.

${ }^{\text {so }}$ traight, "Bureau of Measurements, ${ }^{\circ}$ Vancouver B.S.T. Annual Report for 1928, 63-82; McLaren, Master Race, op. cit., 92. See also Gerald E. Thomson, "Remove From Our Midst These Unfortunates, ${ }^{\circ}$ op. cit. 
ability study of over 22,400 students from grades 3 to 9 . Although data indicated a disparity of results between the wealthy west side of the city and the poorer east side, no efforts were made to upgrade the low achieving schools. Similarly, low high school test scores among technical school students for such academic subjects as French were considered merely natural. ${ }^{51}$ Straight's Bureau maintained the status quo; it did not promote curricular reform. Scientific progressivism led only to the documenting of educational disparities in Vancouver's public schools, not to challenges of them.

Straight's chief task at the Bureau became the promotion of mental measurement as a prime tool of scientific school management. To this end he taught as a sessional lecturer at UBC from 1926 to 1930 , joined by King from 1931 to $1932 .^{52}$ As early as 1922 both Straight and King were promoting educational surveys and testing to the B.C. Teachers Federation. ${ }^{53}$ In 1929 Straight gave a demonstration on "Primary Intelligence Tests" before Federation delegates, and in 1932 wrote an article for The B.C. Teacher on current Canadian, as well as British, intelligence tests in use. ${ }^{54}$ Not all readers agreed with Straight's view that "standardized tests are superior to the traditional or made-on-the-spur-of-the-moment tests, " but he paid little heed..$^{55}$ The Great Depression reduced Straight to a half-time school inspector, but he still administered 16,701 group tests during 1932 and $1933^{56}$ -hardly a work reduction but rather a "doubling up" of duties, according to his son. ${ }^{57}$ The Sunday Province confirmed it was after attending the University of Washington that he "went wholeheartedly into mental measurements," and that "his own importance in school affairs" was due to his role as head of the Bureau. Scientific progressivism was a career vehicle for Straight.

During World War II he branched out into testing adult recruits for the military and university nursing candidates. Aptitude and diagnostic tests were

${ }^{51}$ Straight, "Bureau of Measurements," Vancouver B.S.T. Annual Report for 1929, 54-5.

${ }^{52}$ Department of Education:, UBC Calendar: 1926-1927, Twelfth Session, 100 \& 103; Ibid., UBC Calendar: 1927-1928, Thirteenth Session, 101, 103 \& 104; Ibid., UBC Calendar: 1929-1930, Fifteenth Session, 116; Ibid., UBC Calendar: 1930-1931, Sixteenth Session, 124-125; Ibid., UBC Calendar: 1932-1933, Eighteenth Session.

${ }^{53}$ H.B. King, "Analysis of Recent Education Surveys"; Discussion: Mr. H.H. McKenzie (Inspector Vancouver), Mr. R. Straight (Vancouver) and Mr. H.C. Campbell (Prince Rupert), B.C. Teachers Federation Convention Schedule for April 20, 1922, The B.C. Teacher 1, 7 (March 1922): 12.

${ }^{54}$ Straight, "Primary Intelligence Tests" and Miss Jean Cantelon, "Demonstration Class," The B.C. Teacher 8, 7 (March 1929): 8; Straight, "A Note on Testing," The B.C. Teacher 11, 10 (June 1932): 21-2.

${ }^{35}$ Straight, Ibid; Straight, "The Use and Abuse of Standardized Tests and Objective Tests," B.C. Teachers Federation Convention Schedule for 24 April 1934, The B.C. Teacher 13, 7 (March 1934): 20. See also Jay Ess, "After the Tests-What?," The B.C. Teacher 18, 9 (May 1939): 479-80 and Harry S. Johnston, "Nature and Utility of Standardized Tests," The B.C. Teacher 19, 1 (September 1939): 19-20.

${ }^{56}$ Vancouver B.S.T. Annual Reports for 1932/1933, "Bureau of Measurements," 58-9.

37Interview with Lee Straight, 5 March 1997.

${ }^{58}$ Shem, "Straight," op. cit., 8. 
used to assist students with work placements. ${ }^{59} \mathrm{Near}$ the war's end Straight began to work closely with Dr. C.B. Conway of the Education Department's Testing Service and H.B. King on a provincial testing programme of grade 10 s using the Progressive Achievement Test. He also tracked school absenteeism for a "School Health Survey" sponsored by the Canadian Public Health Association. ${ }^{60}$ Counsellors began to advise parents by letter about children's test results and the outlook for their future careers. In 1941 2,000 letters were sent to parents and in 194217,000 letters. ${ }^{61}$ The Bureau had not only altered school practices but branched into the new fields of mental health and child guidance. Through its promotion of intelligence testing Straight's Bureau not only (in Mona Gleason's term) "psychologized" the classroom, but the wider society as well.

\section{H.B. King and the Track System at Kitsilano Junior High School}

If the platoon system at Tennyson Elementary can be said to have advanced Straight's early career, the creation of Canada's first junior high school did as much for H.B. King. King's later, more prestigious career as Chief Inspector of Schools for the province reveals little of his support for scientific progressivism. In piloting the concept of a junior high school organized with ability tracks for students, King displayed an overriding concern for the appropriate social and economic preparation of youth. King's everyday demeanour was coldly efficient. "Few people who remember King speak favourably of him, usually stressing his vanity, arrogance and intolerance," states A.H. Child. Lee Straight and another charter member of Kitsilano Junior High School remember King as a dreaded authority figure. ${ }^{62}$

King wrote a rather dry description in official accounts of how his new junior high school, Kitsilano, would be set up along with its counterpart, Templeton. There would be 900 students at Templeton and 1,300 at Kitsilano. ${ }^{63}$ What he failed to convey was how students would be selected and assigned to ability tracks in high school. Kitsilano students knew they had been sorted because King "graded all the classes by their I.Q.s." Students were assigned to classes by letters, the " $A$ " stream for the academic and other letters for trades, vocational, and "subnormal" pupils. ${ }^{64}$

In his 1961 thesis on the development of Vancouver secondary education, John Henry Wormsbecker wrote: "Provisions for individual differences among pupils was a basic aim of the junior high school." There were two broad group-

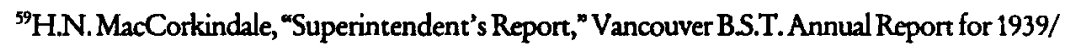
1940, “Bureau of Measurements," 34-5; Robert Straight, "Bureau of Measurements," 98-104.

${ }^{60}$ Straight, "Bureau of Measurements," Vancouver B.S.T. Annual Report for 1945/1946, 131-3.

${ }^{61}$ Straight, "Bureau of Measurements, "Vancouver B.S.T. Annual Report for 1941/1942, 72, 79.

${ }^{62}$ A.H. Child (1974), op. cit., 308; Interview with Lee Straight, 5 March 1997; Interview with Grace Jamieson, 27 February 1997.

${ }^{63}$ H.B. King, "The Present Condition of the Junior High School in British Columbia," The B.C. Teacher 6, 7 (March 1927): 35.

${ }^{64}$ Interview with Lee Straight, 5 March 1997. 
ings of students: those who took French and those who did not. King purposely created a "homogeneous grouping within the grade according to ability" using "Robert Straight's original testing program." Much of Vancouver still operated on the 8-4 plan, 8 years of elementary and 4 years of high school. King's new system was based on a 6-3-3 mode, with grades 1-6 being elementary school, grades 7-9 junior high, and grades 10-12 high school. Junior high would offer academic/vocational streams, while high school would be exclusively academic. ${ }^{65}$

King's central problem was how to unite a school divided into ability tracks. In the first (November 1928) issue of the school newspaper, Kitsilano High School Life, King told students and their parents he wanted to develop a "corporate feeling" in the school through innovative programmes: the school newspaper, school clubs, a house system of sports competition, and a students' council to sponsor dances, pep rallies, and other social activities. Group social and sports activities "contributed to breaking down the barriers between...divisions of the school." In 1934 King declared "greater strides than ever before in the direction of student participation and in the promotion of democratic school citizenship" had been made at Kitsilano. ${ }^{66}$

King in fact encouraged students to accept the social/economic inequalities they would face in later life. Sports and social activities were diversions blunting the fact their life destinies were being determined. King regarded social sorting as a matter of necessity. The "school must provide for individual differences arising from differences in ability," as education in "the progressive state is ... interested in the production of citizens. ${ }^{n 7}$ Marxist historians of education easily construed this to mean the goal was to produce not citizens for a democracy, but rather compliant workers for the needs of the economic superstructure.

The "subnormal" stream at Kitsilano Junior High School under Miss Mackenzie attests to segregation by mental ability. Another "subnormal" class was created a year later at Templeton Junior High. Previously "subnormal" students had attended only elementary special classes, but those with an I.Q. on the Binet Test of 75 or less would now "get the training that will enable them to fit into the community industrially and socially," declared Vancouver's special class supervisor, Miss Josephine Dauphinee. Wormsbecker notes that the "subnormal" students nevertheless remained isolated, their school life "centered around the classroom and their own teacher." Dauphinee admitted that attending high school did increase the "subnormal" child's "self-respect," but the members of "Div. 35"

${ }^{65}$ John Henry Wormsbecker, Jr., "The Development of Secondary Education in Vancouver," $\mathrm{PhD}$ thesis, University of Toronto, 1961, 186-7, 142-5, 154; Wormsbecker was Deputy Superintendent of Vancouver schools in the 1970s.

${ }^{66}$ Ibid., 214-16.

${ }^{67}$ H.B. King, School Finance in British Columbia (Victoria: King's Printer, 1935), 32-3. See also Herbert Baxter King, "The Financing of Education in British Columbia," $\mathrm{PhD}$ thesis, University of Washington, 1936. 
"were mentally the dullest groups in each school. ${ }^{\text {68 }}$ Despite King's insistence on a "corporate feeling" among students, most - even, or perhaps especially, the "subnormal" ones- were always conscious of their school ranking.

Scientific Progressivism in the Post-Second World War Schools of Vancouver

In 1945 H.B. King called the adoption of province-wide progressive school measures or the new education in the post-war era "part of a world-wide trend," but was careful to avoid American references because of "the strength of antiAmerican thought in British Columbia." ${ }^{69}$ That same year King asked his old friend Straight to test 2,282 grade 10 students in Vancouver to establish Canadian norms for the Progressive Achievement Test. Straight was again working with Dr. C.B. Conway of the Education Department to renorm the General Science Test. ${ }^{70}$ King and Straight were still intent upon using standardized tests as quality control mechanisms within the public school system. In October 1948, Straight gave all grade 7 students in Vancouver the Pintner General Ability Test and the Metropolitan Achievement Test as "part of a continent-wide testing program for larger cities in Canada and the United States." (Actually there was only one Canadian norm site-Vancouver—accompanying New York, Philadelphia, Detroit, Cleveland, Baltimore, Pittsburgh, San Francisco, Portland, Dallas, and San Diego.) Sponsored by the World Book Company, the norming programme hoped to realize "continent-wide standards." Straight continued to test students regularly and report on the results through his yearly reports to the school board. In 1947, 9,842 pupils were given group intelligence tests, and 9,249 in 1948. In 1947,720 pupils had individualized psychoeducational assessments using the Stanford Binet Test and in 1948, 795. ${ }^{71}$ In 1951/1952 the Bureau processed over 16,000 pupils through group tests and administered over 1,000 individual pupil assessments. ${ }^{72}$ Students continued to be streamed according to mental ability levels.

H.B. King retired in 1947 and would die in 1956 . He had been a member of the Progressive Education Association but his failing, according to A.H. Child, had been to impose progressivism upon the province's schools in an autocratic manner through a centralized bureaucracy. Although King had always advocated standardized tests, they "were not widely used in 1946" except in Vancouver's schools under Straight's Bureau. ${ }^{73}$

${ }^{68}$ Josephine Dauphinee, "Special Classes," Vancouver B.S.T. Annual Report for 1928, 83-85; John Henry Wormsbecker,Jr. (1961), op. cit., 284-5; Josephine Dauphinee, "Special Classes," Vancouver B.S.T. Annual Report for 1929, 86-7.

${ }^{69}$ A.H. Child (1974), op. cit., 319.

${ }^{70}$ Straight, "Bureau of Measurements," Vancouver B.S.T. Annual Report for 1945/1946, 131-3.

${ }^{71}$ Straight, "Bureau of Measurements," Vancouver B.S.T. Annual Report for 1947/1948, 147-9.

7hareport of the Bureau of Measurements," Vancouver B.S.T. Annual Report for 1951/1952, 12.

${ }^{3}$ A.H. Child (1974), op. cit., 308, 319. 
Ill health forced Straight to retire in June 1951. He died in St. Paul's Hospital on 31 January 1956. His Province obituary called Straight a "veteran educator" and "early enthusiast of progressive education." as head of the Bureau of Measurements in September, 1951. By 1954 the Bureau was split between the Research Division for Testing and a Special Services Division for the investigation of slow learners and truants. ${ }^{75}$ Counsellors began to rely on educational testing to place pupils in programmes such as occupational training, rather than streaming them by mental ability. S.N.F. Chant was a psychologist at UBC who had conducted child study research with Canada's leading child psychologist, Dr. W. E. Blatz, at the University of Toronto. The Chant Report of 1960 reinforced conservative educational values but called for public schools to accept mentally and physically handicapped pupils.

By the late 1950 s scientific progressivism began to fall out of favour in Vancouver and across the province. ${ }^{76}$ As the movement's main proponents retired, its scientific and social rationale was forgotten.

\section{SCIENTIFIC PROGRESSIVISM AND THE ROYAL ROAD TO SCHOOL REFORM}

Callahan has described the efforts of progressive American school administrators as ultimately anti-intellectual, approaching "education in a business-like, mechanical, organizational way." They "saw schools not as centres of learning but as enterprises" turning out appropriately trained graduates in an efficient and economical manner for the industrial economy. ${ }^{77}$ Lost in the process were any notions of creating thinking individuals and, indeed, the individuals themselves. The dilemma for scientific progressives was that if they became too fond of charts and organizational seamlessness, they risked losing sight of the fact they were educating young people to find their places in the world. As prominent Vancouver educators, Robert Sparling, Robert Straight and H.B. King believed they had found the "royal road" to school reform, scientific progressivism. School Inspector J.T. Pollock was careful to warn in his 1920-1921 report on Vancouver schools against educators "who believe in rapid and radical" methods. They should be "wary" of such royal roads to educational reform, particularly from the United States. ${ }^{78}$

In the light of the revaluation of progressive education by historians of North American education since the 1960 s, Pollock's warning now seems timely. But we know Vancouver educators such as Sparling, Straight and King were instru-

74“ Obituary Column: Veteran Educator, R. Straight, Dies," op. cit., 42.

${ }^{75}$ Dr.Selwyn A.Miller, "Department of Research and Special Services, "Vancouver B.S.T. Annual Report for 1954, 13, 15.

${ }^{76}$ A.H. Child (1974), op. cit., 318; See Jean Barman and Neil Sutherland, "Royal Commission Retrospective" in Jean Barman, Neil Sutherland, J. Donald Wilson, eds. (1995), op. cit., 418-19.

"Callahan, Cult, op. cit., 247.

${ }^{78}$ J.T. Pollock, "Report on Inspectorate No. 3," Fiftieth Annual Report of the Public Schools of British Columbia (1920-1921), F23. 
mental in reshaping the schools of Vancouver from the mid-1920s to the late 1940 s according to principles they acquired at University of Washington summer quarters. Any attempts at social betterment through public education must accept that "the majority of students....were thought to be incapable of benefiting from the traditional academic curriculum." ${ }^{79}$ Intelligence testing, student sorting, and a differentiated education was more scientific and efficient than the old system of a minimal education for all. Scientific progressivism did solve the school overcrowding problem, high failure rate in early high school and chronic "retardation rate" of overage pupils retained in the lower grade levels. Vocational and academic tracks did extend schooling for many of Vancouver's pupils into high school. Yet it also preserved social class background. Tested, slotted and sorted at an early age, parental background was more often than not maintained through education. Far from being neutral and scientific, the progressive educational reforms of Straight and King reinforced individual social differences.

Although scientific progressives professed to be "fond of children" as well as charts, their penchant for classification, testing, and ability streaming made it difficult for them to look at each child as a worthwhile individual. Only with the decline in the late 1950s and early 1960 s of this arbitrary educational apparatus did individual pupils with specific sets of needs assume a more prominent role. Scientific progressivism was replaced, according to Sutherland, by the childcentred rhetoric previously confined to educational literature and experimental progressive schools. A page in North American education had turned.

${ }^{79}$ Mann, “Weir and King," op. cit., 96. 